\title{
The Impact of Agro-Ecological Variation on Biological Parameters of Bruchidius atrolineatus Pic (Coleoptera-Chrysomelidae-Bruchinae)
}

\author{
Dan Mairo Adamou Moumouni', Ali Doumma ${ }^{2 *}$, Amadou Harouna Issa ${ }^{1}$ \\ ${ }^{1}$ Faculty of Science and Technology, Abdou Moumouni University of Niamey, Niamey, Niger \\ ${ }^{2}$ Faculty of Sciences and Technics, Abdou Moumouni University of Niamey, Niamey, Niger \\ Email: *doumma@yahoo.com
}

Received 19 November 2015; accepted 4 December 2015; published 8 December 2015

Copyright (C) 2015 by authors and OALib.

This work is licensed under the Creative Commons Attribution International License (CC BY). http://creativecommons.org/licenses/by/4.0/

(c) (i) Open Access

\begin{abstract}
In this study, the biological parameters of two $B$. atrolineatus strains originated from two different agro-ecological areas of Niger are examined. The analysis of the adult lifetime showed that $B$. atrolineatus strain of the Sahelo-Sudanese area lived longer (7.58 \pm 2.19 days) than that of the Sahelian area (7.44 \pm 1.39 days). Furthermore, males lived longer than females regardless of the strain origin. The egg laying activity showed that the eggs laid number was not statistically different according to the two areas. But it appeared that more than $94 \%$ of the eggs were laid in the first four days of cowpea seed infestation. The larvae survival rate and the rate of emergence also varied according to the geographical strain origin. There were few data recorded in Sahelian area where nearly $30 \%$ of the larvae did not reach adult stage. In the Sahelo-Sudanese area, less than $4 \%$ of the hatched larvae reached the adult stage. The sex-ratio also varied according to the geographic strain origins. It was in favor of males in the Sahelian area and was in favor of females in the Sahelo-Sudanese area.
\end{abstract}

\section{Keywords}

Cowpea, Bruchids, Agro-Ecological, Biological Parameters, Niger

Subject Areas: Entomology

\section{Introduction}

Cowpea, Vigna unguiculata (L.) Walp., is a leguminous plant that plays an important role in people’s diet in ${ }^{*}$ Corresponding author.

How to cite this paper: Moumouni, D.M.A., Doumma, A. and Issa, A.H. (2015) The Impact of Agro-Ecological Variation on Biological Parameters of Bruchidius atrolineatus Pic (Coleoptera-Chrysomelidae-Bruchinae). Open Access Library Journal, 2: e2183. http://dx.doi.org/10.4236/oalib.1102183 
Africa and in almost all tropical regions. The seeds of this plant represent an important source of protein in subSaharan countries, and a substitute for proteins of animal origin. Furthermore, cowpea is an important source of income for farmers in West Africa. However, all developmental stages of cowpea are under constant attack by many pest species [1], most of which belong to the subfamily Bruchidae. In Niger, cowpea damage is principally caused by two species of weevils including Bruchidius atrolineatus Pic. and Callosobruchus maculatus Fab. The adults of these two species infest cowpea plant as early as the beginning of flowering season and continue during the harvest and storage. Females of bruchids lay their eggs on the surface of the pods as soon as they begin to form [1], and once the eggs hatch, the larvae penetrate the seeds where they find nutritious substances to continue their post-embryonic development. The larvae and pupae become already present active. During the early phase of storage of cowpea pods and seeds, the level of infestation caused by these pests is generally less than 5\% [2]. This rate can increase to $30 \%$ in just one month of storage, and $80 \%$ to $100 \%$ within 5 to 6 months if no appropriate control measures are taken [3]-[5]. Among the two species of weevil, Bruchidius atrolineatus is the species that is primarily responsible for damage in the field and during the storage of cowpea. In fact, our previous studies in the region of Niamey, Niger, have shown that $80 \%$ to $90 \%$ of the harvested cowpea pods were infested with B. atrolineatus eggs. Approximately $90 \%$ of the bruchids emerging from these pods during the first three months of storage belong to this species [6] [7]. Damaged seeds can be completely hollowed out by feeding larvae, causing a severe loss of seed weight, nutrition, germination potential, and thereby the commercial value of the commodity [8].

In order to reduce the damage caused by cowpea weevils, several control measures have been developed and tested. These methods include the use of insecticides, repellent plants, essential oils, ash and many others [9][12]. However, it is clearly accepted that a deep understanding of the bio-ecology of the pest species is critical for the success of any control measure. The bio-ecological parameters were greatly depended on the climatic factors that influenced the development and reproduction of the pest species [13]. This is particularly important for the largest country like Niger with four different agro-ecological areas. The objective of the present study is to characterize the B. atrolineatus strain of Niger by determining its biological parameters such as life span, fertility, development time and survival rate in different developmental stages.

\section{Materials and Methods}

\subsection{Materials}

The strains of B. atrolineatus used in this study were taken from the cowpea seeds and pods collected from producers of the locality of Gaya ( $11^{\circ} 53^{\prime} 3 \mathrm{~N}$ and $3^{\circ} 26^{\prime} 57 \mathrm{E}$, Sahelo-Sudanese area, Dosso region), and the region of Niamey (13 $30^{\prime} 49 \mathrm{~N}$ and $2^{\circ} 6^{\prime} 35 \mathrm{E}$, Sahelian area). The characteristics of these two localities are indicated in Table 1. The infested cowpea seeds (6 to $9 \mathrm{~kg}$ ) were collected from producers in each of two localities. These samples were transported to the laboratory and stored in parallelepiped plexiglas bottles of size $260 \times 130 \times 77$ $\mathrm{cm}$. The infested seeds were kept there until adult insects emerged and then would be reared and used for the experiments.

\subsection{Methods}

After the emergence, the content of each bottle was sieved and the adult's bruchids were collected and placed in clean bottles containing 100 to $120 \mathrm{~g}$ of non infested seeds for laying eggs. The bruchids were placed in bottles containing the seeds from the same locality, where it's were originally collected. After $48 \mathrm{~h}$, the insects were removed from the bottles and the infested grains were kept again until emergence. The emerging adults were then collected and used for analysis of bio-ecological parameters.

Table 1. Agro-climatic references of the localities studied.

\begin{tabular}{|c|c|c|c|}
\hline Localities & Agro-climatic zone & Rainfall & Geographical coordinates \\
\hline Niamey & Sahelian zone & 400 à 600 mm & $\begin{array}{c}13^{\circ} 30^{\prime} 49^{\prime \prime} \mathrm{N} \text { et } \\
2^{\circ} 6^{\prime} 35^{\prime \prime} \mathrm{E}\end{array}$ \\
\hline Gaya & Sahelo-Sudanese zone & Plus de 600 mm & $\begin{array}{c}11^{\circ} 53^{\prime} 3 \mathrm{~N} \text { et } \\
3^{\circ} 26^{\prime} 57 \mathrm{E}\end{array}$ \\
\hline
\end{tabular}

Source: AGRHYMET (NIGER). 


\subsubsection{Experimental Procedure}

The experiment consisted to put a couple of B. atrolineatus in a petri dish containing 10 healthy seeds of cowpea (Vigna unguiculata L. Walp). Daily, the seeds are replaced by new seeds in the petri dishes, until the complete death of insects.. After 10 days, the infested seeds were analyzed for the number of laid eggs and kept until adult emergence. This experiment was repeated 20 times for each of the two strains. Different parameters of B. atrolineatus were established including:

- Adults longevity: number of days from emergence to death.

- The number of eggs laid by females $(\mathrm{N})$ : the total eggs laid on the seeds during the lifespan of a female.

- The developmental time: The number of days between the laying of an egg and the emergence of adult from that egg.

- The fertility rate: The ratio between the number of fertile eggs and the total number of eggs laid.

- Larval survival rate (S): The ratio between the total number of emerged adults and the total number of fertile eggs multiplied by 100 .

- Emergence rate: The ratio between the total number of emerged adults and the total number of eggs laid.

- The sex-ratio: The ratio of male and female in the offspring.

\subsubsection{Embryonic Development Time}

To determine the embryonic development time, one cowpea seed containing only one newly laid egg was introduced in a petri dish for each of the strains. The egg was observed daily until the $10^{\text {th }}$ day of experiment and the number of hatched eggs was recorded every day. For each strain the experiment was repeated 50 times. Sterile eggs differ from the fertile eggs by their translucent appearance.

\subsection{Data Analysis}

The STAT VIEW software. rar. Version 1999 was used for data analysis. The variance analysis (ANOVA or MANCOVA) was computed. The pairwise comparison of the means was performed using Fisher procedure at 5\% significance level.

\section{Results}

\subsection{Longevity of Bruchidius atrolineatus Adults}

The statistical analysis showed that the Sahelo-Sudanese strain of B. atrolineatus lived relatively longer (7.58 \pm 2.19 days) than the Sahelian strain (7.44 \pm 1.39 days). The longevity of females of the two bioclimatic areas was not statistically different. However, the longevity of male varied depending on the geographic origin of the strain. Our results also showed that the males of the Sahelo-Sudanese (Gaya) strain lived longer (7.65 days) than those of the Sahelian area (Niamey) (7.47 days). For both strains, males lived longer than females (Table 2).

\subsection{Survival Curve of $B$ a atrolineatus Based on Agro-Climatic Area}

During the first two days of the experiment, all the adults of B. atrolineatus of the different strains remained alive (Figure 1). The beetles started to die at the third day (J3) for the Sahelian area strain and at the fourth day (J4) for that of the Sahelo-Sudanese strain. The adult mortality was observed every day from the third day (J3) for Sahelian area strain and forth day (J4) for those of sahelo-Sudanese until all the insects were deaden. This mortality was more spread for Sahelo-Sudanese strain for whom some adults still alive until day12 (J12), whereas no survivor was found after 10 days (J10) for the adults of the Sahelian strain.

Table 2. Longevity of B. atrolineatus based on agro-climatic zones.

\begin{tabular}{cccc}
\hline Agro-climatic areas & Average longevity of female (days) & Average longevity of male (days) & Average longevity (days) \\
\hline Sahelian area & $7.42 \pm 1.34 \mathrm{a}$ & $7.47 \pm 1.46 \mathrm{a}$ & $7.44 \pm 1.39 \mathrm{a}$ \\
Sahelo-Sudanese area & $7.52 \pm 2.08 \mathrm{a}$ & $7.65 \pm 1.63 \mathrm{~b}$ & $7.58 \pm 2.19 \mathrm{~b}$ \\
\hline
\end{tabular}

NB: Means followed by the same letter(s) are not significantly different at the 5\% level (Test of Newman and Keuls). 


\subsection{Eggs Laying Activity}

The mean of eggs laid by female of B. atrolineatus from the two agro-ecological areas was presented in Table 3 . The results showed that for both strain, there was no significant variation in realized fecundity and egg fertility $((P=0.847)$. The mean of eggs laid by female was $35.50 \pm 15.42$ eggs for Sahelo-Sudanese strain and $34.93 \pm$ 17.25 eggs for Sahelian strain. Egg fertility rate recorded for the two strains was very important and higher than $94 \%$.

\subsection{Daily Evolution of $B$. atrolineatus Fecundity Based on Agro-Ecological Areas}

For both strains, females began to oviposit as early as the first day of experiment (Figure 2). However, more than $94 \%$ of eggs were laid during the first four days of B. atrolineatus life. Thus it appeared that more than $98 \%$ and $94 \%$ of eggs were laid during the first four days of the infestation for Sahelian and Sahelo-Sudanese strain, respectively. The highest number of eggs laid by females was observed at the second day (J2) for the strain of the Sahelo-Sudanese area and third day (J3) for the Sahelian strain (Table 4).

\subsection{Larval Survival and Emergence Rates}

The results reported in Table 5 indicated the larval survival and adults' emergence rate observed in the two agro-ecological areas. The analysis of these results showed that more larvae survived in the Sahelo-Sudanese area $(96.43 \%)$ than in the Sahelian area $(70.10 \%)$. Moreover, larval mortality rate was relatively higher in the Sahelian area where a mortality rate of $30 \%$ was recorded. This rate was higher than the mortality observed in the Sahelo-Sudanrese area where the larval mortality was less than $4 \%$. These important variations in the larval survival rate resulted a low emergence rate of $B$. atrolineatus adults in Sahelian area where adults' emergence rate of $66.47 \%$ was recorded.

\subsection{Embryonic and Larvae Developmental Time}

For both strains, there was no significant difference in the embryonic developmental time. The eggs laid on the seeds gave rise to L1 larval after $5.06 \pm 1.07$ and $4.72 \pm 1.06$ days for the Sahelian and Sahelo-Sudanrese strains,

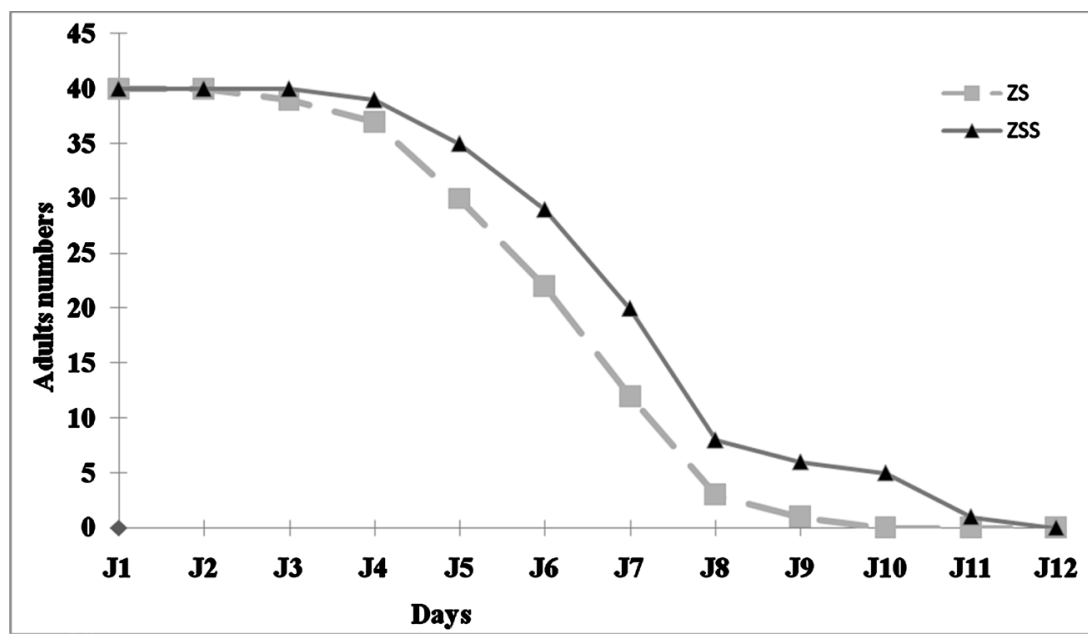

Figure 1. Survival curve of B. atrolineatus based on agro-climatic area. ZS: Sahelian zone, ZSS: Sahelo-sudanese zone.

Table 3. Average number of egg laid, hatched and fertility rate of B. atrolineatus base on agro-ecological origin.

\begin{tabular}{|c|c|c|c|}
\hline Agro-climatic areas & Average number of eggs/female & Average number of hatched eggs/female & Egg fertility rate\% \\
\hline Sahelian zone & $34.93 \pm 17.25 a$ & $33.12 \pm 16.29 a$ & $94.81 \%$ \\
\hline Sahelo-Sudanese zone & $35.50 \pm 15.42 \mathrm{a}$ & $33.66 \pm 15.25 a$ & $94.81 \%$ \\
\hline
\end{tabular}

N.B: Means followed by the same letter(s) are not significantly different at the $5 \%$ level (Test of Newman and Keuls). 
respectively. However, the average larvae developmental time was significantly higher for the Sahelian strain (34.64 \pm 3.00 days) than for Sahelo-Sudanrese strain (32.73 \pm 3.73 days) (Table 6).

\subsection{Sex Ratio Variation}

The B. atrolineatus sex ratio varied according to the geographical origin of the strains. Thus, the analysis of the results indicated that the sex ratio was in favor of males (under 50\%) in the Sahelian area, while more females (over 50\%) were produced in sahelo-Sudanese area (Table 7).

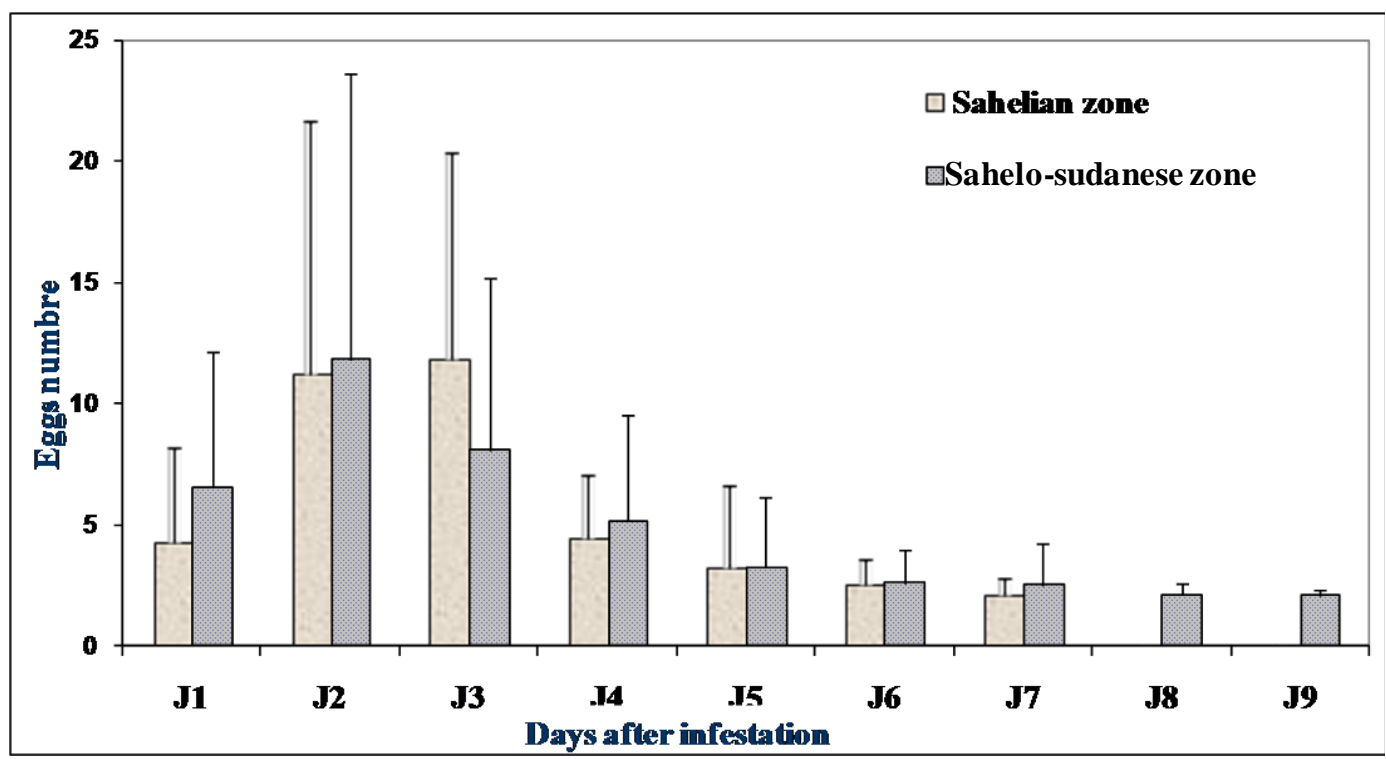

Figure 2. Daily evolution of the number of eggs laid by B. atrolineatus female according to agroclimatic zones.

Table 4. Percentage of eggs laid during the life span of B. atrolineatus female.

\begin{tabular}{cccccc}
\hline Strain origin & First day & First two days & First three days & First four days & Remaining time of the experiment \\
\hline Sahelian area & 46.49 & 84.30 & 90.29 & 98.14 & 1.86 \\
Sahelo-Sudanese area & 51.24 & 76.35 & 89.42 & 94.61 & 5.39 \\
\hline
\end{tabular}

Table 5. Embryonic and larval development periods observed for the two strains of B. atrolineatus.

\begin{tabular}{ccc}
\hline Strain origin & Embryonic developmental time (days) & Larvae developmental time (days) \\
\hline Sahelian zone & $5.06 \pm 1.07 \mathrm{a}$ & $34.64 \pm 3.00 \mathrm{a}$ \\
Sahelo-Sudanese area & $4.72 \pm 1.06 \mathrm{a}$ & $32.73 \pm 3.73 \mathrm{~b}$ \\
\hline
\end{tabular}

N.B: Means followed by the same letter(s) are not significantly different at the $5 \%$ level (Test of Newman and Keuls).

Table 6. Larvae survival rate and emergence rate observed in the two agro-ecological zones.

\begin{tabular}{ccccc}
\hline Strain origin & $\begin{array}{c}\text { Average number } \\
\text { of eggs/female }\end{array}$ & $\begin{array}{c}\text { Average number of } \\
\text { hatched eggs/females }\end{array}$ & $\begin{array}{c}\text { Average number } \\
\text { of adults }\end{array}$ & $\begin{array}{c}\text { Larvae survival } \\
\text { rate }\end{array}$ \\
\hline Sahelian Zone & $34.93 \pm 17.25 \mathrm{a}$ & $33.12 \pm 16.29 \mathrm{a}$ & $23.22 \pm 10.23 \mathrm{a}$ & $70.10 \%$ \\
rate & $35.50 \pm 15.42 \mathrm{a}$ & $33.66 \pm 15.25 \mathrm{a}$ & $32.46 \pm 9.27 \mathrm{~b}$ & $96.43 \%$ \\
\hline
\end{tabular}

N.B: Means followed by the same letter(s) are not significantly different at the $5 \%$ level (Test of Newman and Keuls). 
Table 7. Sex-ratio of B. atrolineatus in the two agro-ecological zones.

\begin{tabular}{ccc}
\hline Agro-ecological zones & Number of emerged adults & Number of emerged females \\
\hline Sahelian Zone & $23.22 \pm 10.23 \mathrm{a}$ & $10.57 \pm 6.16 \mathrm{a}$ \\
Sahelo-Sudanese zone & $32.46 \pm 9.27 \mathrm{~b}$ & $23.23 \pm 8.05 \mathrm{~b}$ \\
\hline
\end{tabular}

N.B: Means followed by the same letter(s) are not significantly different at the $5 \%$ level (Test of Newman and Keuls).

\section{Discussion}

The most important finding of this study is that populations of B. atrolineatus originating from within a relatively small geographical area, in Niger, have been found to exhibit measurable and significant differences in various biological traits associated with developmental performance. The analysis of the adult life time showed that $B$. atrolineatus strain of the Sahelo-Sudanese area lived longer (7.58 \pm 2.19 days) than those of the Sahelian area (7.44 \pm 1.39 days). Comparatively, longevity of the sympatric species of B. atrolineatus in cowpea storage, Callosobruchus maculatus live was less than 6 days regardless of the agro-climatic zone [13]. The results showed that the males lived longer than females regardless of the strain origin. These results can be explained by the intensive egg laying activity of females which involved a significant reduction of their longevity. This may be caused by the massive use of nutrients in the development and maturation of ovocyte. Furthermore, it has been suggested that mating activity significantly affect female lifetime [5], in animal kingdom. The cost of reproduction has been extensively studied in many insects [14]-[17]. The trade-off between mating and longevity has also been reported for the cowpea bruchid [18]. A commonly accepted explanation for the negative impact was that mating may divert limited resources to activities associated with reproduction such as courtship, copulation, egg production and sperm donation, thereby reducing resources available for somatic maintenance [15] [17]-[19].

The analysis of the egg laying activity showed that more than $94 \%$ of the eggs were laid in the first four days of cowpea seed infestation as observed on C. subinnotatus by [20] and on C. maculatus by [13]. The larvae survival rate and the rate of emergence also varied according to the geographical origin of the strain. There were few data recorded in Sahelian area where nearly $30 \%$ of the larvae did not reach adult stage. Similarly, in the Sahelo-Sudanese area less than $4 \%$ of the hatched larvae reached the adult stage. The higher mortality rate observed in Sahelian area, suggested that adults originating from this geographical area seemed to enter in diapause earlier than those of the Sahelo-Sudanese area. Moreover, many authors indicated that $B$. atrolineatus adults were affected by reproductive diapause induced during the development of the insect [21] [22]. The sexratio also varied according to the geographic origin of the strains. It was in favor of males in the Sahelian area and was in as of females in the Sahelo-Sudanese area. These results were different with those observed on Callosobruchus maculatus where the sex-ratio was in favor of the females in Sahelian area (Niamey) [13]. Differences in biological traits among populations collected from different countries and/or continents have already been reported by numerous authors. For instance, [23] reported a significant variation in parameters associated with development and survival among three strains of $C$. maculatus from Brazil, the Yemen Arab Republic and Nigeria, infesting cowpeas. [24] observed a significant genetic differences in the preference of cowpeas and other legumes among strains of $C$. maculatus originated from different countries, and also indicated an inter-strains differences in fecundity in this species [24]. Differences observed among populations could have arisen via a number of processes acting on the parent populations from which there were originated. It should be explained by the long-term adaptation to the local environmental and/or storage conditions occurring across a country [25]. According to these authors, population differences could also arise because of adaptation to different host varieties or species occurring in different locations. Excluding egg fertility and embryonic development period, most of the other measured parameters, including life span, fecundity, larval development, and larval mortality showed significant differences among populations on the two strains.

\section{Conclusion}

The comparison of biological parameters of the strains of B. atrolineatus originated from two different agroecological areas of Niger shows that the reproductive capacity of this pest is very important under all the climate conditions with only slight variations, depending on the origin of the strains studied. These results are of great importance in the development of integrated pest management strategy against this species. 


\section{References}

[1] Huignard, J., Glitho, I.A., Monge, J.P. and Regnauft-Roger, C. (2011) Insectes ravageurs des grains de léguùineuses: biologie des Bruchinea et lute raisonnée en Afrique. Editor: QUAE, France, 145 p.

[2] Amevoin, K., Glitho, I.A., Monge, J.P. and Huignard, J. (2005) Why Callosobruchus rhodesianus Causes Limited Damage during Storage of Cowpea Seed in a Tropical Humid Zone in Togo. Entomologia Experimentalis et Applicata, 166, 175-182. http://dx.doi.org/10.1111/j.1570-7458.2005.00321.x

[3] Seck, D., Sidibé, B., Haubruge, E., Lienard, V. and Garpar, C. (1992) La Résistance variétale du niébé (Vigna unguiculata (L) Walp.) à Callosobruchus maculatus F. (Col. Bruchidæ): Evaluation et perspectives d'utilisation au Sénégal. Mededelingen Faculteit Landbouwwetenschappen Rijksuniversiteit Gent, 57, 743-750.

[4] Ouedraogo, A.P., Sou, S., Sanon, A., Monge, J-P., Huignard, J., Tran, B. and Credland, P.F., (1996) Influence of Temperature and Relative Humidity on Population of Callosobruchus maculatus (Coleoptera: Bruchidae) and Its Parasitoid Dinarmus basalis (Pteromalidae) in Two Climatic Zones of Burkina Faso. Bulletin of Entomological Research, 86, 695-702. http://dx.doi.org/10.1017/S0007485300039213

[5] Sanon, A., Sou, S., Dabire, L.C.B., Ouedraogo, A.P. and Huignard, J. (2005) Combining Boscia senegalensis Lamarck (Capparaceae) Leaves and Augmentation and the Larval Parasitoid Dinarmus basalis Rondani (Hymenoptera: Pteromalidae) for Bruchids Control Instored Cowpea. Journal of Entomology, 2, 40-45. http://dx.doi.org/10.3923/je.2005.40.45

[6] Monge, J.P. and Huignard, J. (1991) Populations Fluctuations of Two Bruchids Species Callosobruchus maculatus F. and Bruchidius atrolineatus Pic. (Coleoptera) and Their Parasitoids Dinarmus basalis Rond. (Hymenoptera: Pteromalidae) and Eupelmus vuilleti Craw. (Hymenoptera: Eupelmidae) in a Storage Situation in Niger. Journal of African Zoology, 105, 87-196.

[7] Ajayi, F.A. and Wintola, H.U. (2006) Suppression of the Cowpea Bruchid Callosobruchus maculatus (F.) Infesting Stored Cowpea (Vigna unguiculata (L.) Walp) Seeds with Some Edible Plant Product Powders. Pakistan Journal of Biological Sciences, 9, 1454-1459. http://dx.doi.org/10.3923/pjbs.2006.1454.1459

[8] Boeke, S.J., Baumgart, I.R., van Loon, J.J.A., Van Huis, A., Dicke, M. and Kossou, D.K. (2004) Toxicity and Repellence of African Plants Traditionally Used for the Protection of Stored Cowpea against Callosobruchus maculates. Journal of Stored Products Research, 40, 423-438. http://dx.doi.org/10.1016/S0022-474X(03)00046-8

[9] Abdullahi, N. and Majeed, Q.N. (2010) Evaluations of the Efficacy of Vittellariaparadoxa Seed Powder on the Oviposition Eggs Viability and Mortality of Callosobruchus maculates (F.) (Coleoptera: Bruchidae) on Treated Cowpea Seed. African Journal of General Agriculture, 6, 289-293.

[10] Singh, R. (2011) Evaluation of Some Plant Products for Their Oviposition Deterrent Properties against the Callosobruchus maculatus (F.) on Chik Pea Seeds. Journal of Agricultural Technology,7, 1363-1367.

[11] Olufunmilayo Ajayi, E., Arthur Appel, G. and Henry Fadamiro, Y. (2014) Fumigation Toxicity of Essential Oil Monoterpenes to Callosobruchus maculatus (Coleoptera: Chrysomelidae: Bruchinae). Journal of Insects, 2014, Article ID: 917212.

[12] Lale, N.E.S. and Vidal, S. (2003) Effect of Constant Temperature and Humidity on Oviposition and Development of Callosobruchus maculatus (F.) and Callosobruchus subinnotatus(Pic) on Bambara Groundnut, Vigna subterranean (L.) Verdcourt. Journal of Stored Products Research, 39, 459-470. http://dx.doi.org/10.1016/S0022-474X(01)00028-5

[13] Doumma, A. (2012) Influence de deux alternatives de lutte sur les capacités reproductrices de Callosobruchus maculatus Fab. (Coleoptera-Bruchidae), ravageur du niébé (Vigna unguiculata Walp.). Thèse de Doctorat D’Etat, L’Université Abdou Moumouni de Niamey, Niamey, 171 p.

[14] Sagarra, L.A., Vincent, C. and Stewart, R.K. (2002) Impact of Mating on Anagyrus kamali Moursi (Hym., Encyrtidae) Lifetime Fecundity, Reproductive Longevity, Progeny Emergence and Sex Ratio. Journal of Applied Entomology, 126, 400-404. http://dx.doi.org/10.1046/j.1439-0418.2002.00679.x

[15] Kotiaho, J.S. and Simmons, L.W. (2003) Longevity Cost of Reproduction for Males but No Longevity Cost of Mating or Courtship for Females in the Male-Dimorphic Dung Beetle Onthophagusbinodis. Journal of Insect Physiology, 49, 817-822. http://dx.doi.org/10.1016/S0022-1910(03)00117-3

[16] Messina, F.J. and Fry, J.D. (2003) Environment-Dependent Reversal of a Life History Tradeoff in the Seed Beetle Callosobruchus maculatus. Journal of Evolutionary Biology, 16, 501-509. http://dx.doi.org/10.1046/j.1420-9101.2003.00535.x

[17] Onagbola, E.O., Fadamiro, H.Y. and Mbata, G.N. (2007) Longevity, Fecundity, and Progeny Sex Ratio of Pteromalus cerealellae in Relation to Diet, Host Provision, and Mating. Biological Control, 40, 222-229. http://dx.doi.org/10.1016/j.biocontrol.2006.10.010

[18] Clutton-Brock, T. and Langley, P. (1997) Persistent Courtship Reduces Male and Female Longevity in Captive Tsetse 
Flies Glossina morsitans Westwood (Diptera: Glossinidae). Behavioral Ecology, 8, 392-395. http://dx.doi.org/10.1093/beheco/8.4.392

[19] Paukku, S. and Kotiaho, J.S. (2005) Cost of Reproduction in Callosobruchus maculatus: Effects of Mating on Male Longevity and the Effect of Male Mating Status on Female Longevity. Journal of Insect Physiology, 51, 1220-1226. http://dx.doi.org/10.1016/j.jinsphys.2005.06.012

[20] Nyamador, S.W. (2009) Influence des traitements à base d’huiles essentielles sur les capacités de reproduction de Callosobruchus subinnotatus Pic.et de Callosobruchus maculatus F. (Coléoptera: Bruchidæ): 152 Mécanisme d'action de l’huile essentielle de Cymbopogon giganteus Chiov. Thèse de Doctorat, Université de Lomé, Lomé, 197 p.

[21] Glitho, I.A. (1990) Les Bruchidae ravageurs de Vigna unguiculata Walp. en zone guinéenne. Analyse de la diapause reproductrice chez les mâles de Bruchidus atrolineatus Pic. Thèse de Doctorat, Université Francois-Rabelais, Tours, $100 \mathrm{p}$.

[22] Lenga, A. (1991) La diapause reproductrice chez Bruchidius atrolineatus Pic. Conséquences physiologiques et évolutives-Analyse de la variabilité des réponses aux facteurs inducteurs de la diapause. Thèse de Doctorat ès-Sciences, Université Francois-Rabelais, Tours, 109 p.

[23] Dick, K.M. and Credland, P.F. (1984) Egg Production and Development of Three Strains of Callosobruchus maculatus (F.) (Coleoptera: Bruchidae). Journal of Stored Products Research, 20, 221-227. http://dx.doi.org/10.1016/0022-474x(84)90007-9

[24] Wasserman, S.S. (1984) Genetic Variation in Adaptation to Food Plant of the Southern Cowpea Weevil, Calloso- bruchus maculatus: Evolution of Oviposit Preference. Entomologia Experimentalis et Applicata, 42, 201-212. http://dx.doi.org/10.1111/j.1570-7458.1986.tb01023.x

[25] Appleby, J.H. and Credland, P.F. (2006) Variation in Responses to Susceptible and Resistant Cowpeas among West African Populations of Callosobruchus maculatus (Coleoptera: Bruchidae). Journal of Economic Entomology, 96, 489502. http://dx.doi.org/10.1093/jee/96.2.489 